\title{
REAKSI PASAR MODAL DARI DAMPAK PERISTIWA BOM PLAZA SARINAH TERHADAP ABNORMAL RETURN PERUSAHAAN LQ 45 YANG TERDAFTAR DI BEI
}

\author{
Ika Yustina Rahmawati \\ Fakultas Ekonomi dan Bisnis, Universitas Muhammadiyah Purwokerto \\ rahmawatirahma2015@gmail.com ${ }^{1}$ \\ Tiara Pandansari \\ Fakultas Ekonomi dan Bisnis, Universitas Muhammadiyah Purwokerto \\ tiarapandansari@gmail.com ${ }^{2}$
}

\begin{abstract}
The purpose of this study was to analyze the reaction of the capital market from the impact of the bombing in Jakarta Sarinah Plaza, which will be indicated by the presence or absence of abnormal return. the sample used is the stock of $L Q 45$, this study is event study so that the observation period will see the reaction on before, during and after the event. In this study period used was $H-5$ (before the event), HO (current events) and $H+5$ (after the event). Sources of data obtained from yahoo finance, sahamok.com and IDX. The data used in this research is secondary data, such as the closing price of shares has been adjusted (adjusted closing price) and the closing price of IHSG. Data in the form of daily stock price. The data was then analyzed using analytical methods paired sample $t$-test. The results showed that when viewed from the average abnormal return (AAR) did not show any difference, only the $\mathrm{H}+3$ and $\mathrm{H}+4$ which shows the differences in AAR and signaled their reaction to the stock market to these events that affect market participants in make decisions.
\end{abstract}

Keywords: Average Abnormal Return (AAR), event study, Bomb Sarinah Plaza.

\section{Pendahuluan}

Setiap peristiwa besar dalam suatu negara pasti akan menimbulkan dampak pula terhadap bidang yang lain, sama halnya dengan para pelaku pasar yang akan sensitif terhadap berbagai informasi yang berkaitan dengan bidang ekonomi, politik, sosial maupun budaya. Bagi para peneliti di bidang keuangan atau para pelaku di pasar seringkali mengamati sebuah peristiwa (event) untuk melihat pengaruh terhadap kondisi lingkungan suatu perusahaan, dalam hal ini sangat erat kaitannya dengan pergerakan saham-saham di pasar modal.

Peristiwa yang dimaksud adalah peristiwa yang terjadi dalam internal perusahaan dan external perusahaan. Peristiwa internal perusahaan biasanya terjadi akibat adanya kebijakan yang dibuat oleh pimpinan, misalnya kebijakan dividen, kebijakan ekspansi, kebijakan merger/akuisisi, kebijakan mengenai pendanaan dan masih banyak kebijakan internal perusahaan yang akan membawa signal atau informasi bagi para investor. Peristiwa external merupakan peristiwa yang terjadi diluar kebijakan yang dibuat oleh perusahaan, misalnya kenaikan harga BBM, bom di JW Marriot, lengsernya presiden Soeharto atau pemilihan umum (PEMILU), dan banyak peristiwa lainnya yang secara tidak langsung akan berpengaruh terhadap tingkat kestabilan kondisi perekonomian pada suatu negara.

Penelitian yang mengacu pada peristiwa (event study) pertama dilakukan oleh Fama, et al. (1969) dalam bidang ekonomi keuangan. Beberapa penelitian sebelumnya yang telah melakukan penelitian event study adalah Sirait. dkk (2012), peristiwa yang diangkat adalah pergantian Sri Mulyani sebagai menteri keuangan pada tahun 2010 dengan hasil penelitiannya menyebutkan bahwa pada sektor perbankan terdapat perbedaan Average Abnormal return (AAR) sebelum, saat dan sesuah peristiwa pengumuman pergantian mentri keuangan. Lamasigi. dkk (2002) yang melakukan penelitian mengenai event study pergantian presiden RI tanggal 23 Juli 2001 pada saham LQ 45 menyebutkan hasil penelitiannya bahwa terdapat positif abnormal return sebelum dan sesudah event.

Rangkaian penelitian event study diatas merupakan peristiwa-peristiwa yang telah terjadi di Indonesia yang memberikan hasil penelitian yang beragam dan memiliki tingkat sensitifitas informasi yang beragam pula untuk investor. Seperti yang terjadi pada awal tahun 2016 tepatnya hari Kamis tanggal 14 Januari 2016 pukul 10.40 WIB, Jakarta kembali 
diguncang oleh peristiwa teror bom dengan lokasi yang dituju adalah Plaza Sarinah.

Berdasarkan pada peristiwa tersebut maka penelitian ini akan mengangkat event study: peristiwa bom Sarinah di Jakarta 14 Januari 2016 yaitu untuk melihat perubahan tingkat AAR (Average Abnormal return) sebelum, saat dan sesudah peristiwa tersebut sehingga akan terlihat rekasi pasar modal dan tingkat sensitifitas informasi ini untuk investor.

Berdasarkan latar belakang tersebut maka peneliti menetapkan rumusan masalah sebagai berikut: (1) Apakah terdapat perbedaan Average Abnormal return (AAR) sebelum dan saat peristiwa bom Plaza Sarinah?, (2) Apakah terdapat perbedaan Average Abnormal return (AAR) saat dan sesudah peristiwa bom Plaza Sarinah? (3) Apakah terdapat perbedaan Average Abnormal return (AAR) sebelum dan sesudah peristiwa bom Plaza Sarinah?

Berdasarkan rumusan masalah diatas maka penelitian ini memiliki tujuan sebagai berikut: (1) Untuk menguji perbedaan Average Abnormal return (AAR) sebelum dan saat peristiwa bom Plaza Sarinah. (2) Untuk menguji perbedaan Average Abnormal return $(A A R)$ saat dan sesudah peristiwa bom Plaza Sarinah. (3) Untuk mengetahui perbedaan Average Abnormal return (AAR) sebelum dan sesudah peristiwa bom Plaza Sarinah.

\section{Kajian Pustaka dan Pengembangan Hipotesis $\square$ Pasar Modal}

Secara klasik pengertian pasar modal adalah suatu bidang usaha perdagangan surat-surat berharga seperti saham, obligasi dan sekuritas efek, sebagai salah satu pelaku ekonomi maka aspek memperoleh keuntungan yang optimal adalah tujuan yang menjiwai pasar modal sebagai lembaga jual beli efek (Sartono, 1999).

Seperti yang telah disampaikan secara singkat pada pendahuluan, bahwa pasar modal menjalankan dua fungsi utama yaitu fungsi ekonomi dan fungsi keuangan. Pasar modal dalam melaksanakan fungsi ekonominya, menyediakan fasilitas untuk memindahkan dana dari pihak yang memiliki kelebihan dana (lender) kepada pihak yang memerlukan dana (borrower). Fungsi pasar modal yang kedua adalah menjalankan fungsi keuangan dimana pasar modal menyediakan dana yang diperlukan oleh para borrower dan lender menyediakan dana tanpa harus terlibat langsung dalam kepemilikan aktiva riil yang diperlukan untuk investasi tersebut (Husnan, 2009).

Kegiatan pasar modal di Indonesia resmi dimulai pada tahun 1977. Dalam perkembangannya tidak terlepas dari kondisi ekonomi dan moneter yang fluktuatif. Dalam kondisi pasar modal yang efisien diharapkan adanya hubungan yang postif antara resiko dan keuntungan yang diharapkan (expected return), (Husan, 2009).

\section{Pasar Modal Efisien}

Suatu pasar dikatakan efisien apabila harga sekuritas-sekuritasnya mencerminkan semua informasi yang relevan dengan segera. Karena itu konsep efisiensi lebih tepat ditafsirkan sebagai konsep yang continuum bukan dikotomi. Semakin cepat suatu pasar bereaksi terhadap informasi baru semakin efisien pasar tersebut. Tetapi apa yang dimaksud dengan relevan? Fama (1970) mengklasifikasikan informasi menjadi tiga tipe yaitu: (1) perubahan harga di waktu yang lalu (past price change), (2) informasi yang tersedia kepada publik (public information), dan (3) informasi yang tersedia baik kepada publik maupun tidak (public and private information).

Bodie, et al. (2011) menyatakan bahwa ada tiga bentuk untuk menyatakan efisien pasar modal, yaitu:

1. Bentuk efisiensi yang lemah (weak form efficiency)

Dalam keadaan seperti ini pemodal tidak dapat memperoleh tingkat keuntungan di atas normal dengan menggunakan trading rules yang berdasarkan atas informasi harga di masa lalu.

2. Bentuk efisiensi setengah kuat (semi strong) Dengan kata lain, para pemodal tidak dapat memperoleh keuntungan di atas normal dengan memanfaatkan public information.

3. Bentuk efisiensi yang kuat (strong forms)

Dalam keadaan semacam ini pasar modal akan seperti rumah lelang yang ideal: harga selalu wajar dan tidak ada investor yang mampu memperoleh perkiraan yang lebih baik mengenai harga saham.

Dari beberapa penelitian yang sudah dilakukan di Indonesia maka pasar modal Indonesia mengarah pada pasar modal efisien dalam bentuk lemah (weak form efficiency), yang dibuktikan oleh hasil penelitian dari Dosinta (2004) dan Wicaksono (2005). 


\section{Studi Perstiwa (Event study)}

Secara definisi studi peristiwa (event study) merupakan studi yang mempelajari reaksi pasar terhadap suatu peristiwa (event), yang informasinya dipublikasikan sebagai suatu pengumuman. Event study ini dapat digunakan untuk menguji kandungan informasi (information content) dari suatu pengumuman (Hartono, 2014).

Pengujian kandungan informasi dimaksudkan untuk melihat reaksi dari suatu pengumuman atau peristiwa. Jika mengandung informasi maka pasar diharapkan akan bereaksi, reaksi pasar ditunjukkan dengan adanya perubahan harga dari sekuritas yang bersangkutan, reaksi ini dapat diukur dengan menggunakan abnormal return. (Hartono, 2014)

Mackinlay (1997) dalam Setyawasih (2007) menyebutkan bahwa ada langkah- langkah yang harus diperhatikan dalam melakukan event study diantaranya adalah:

1. Mendefinisikan kejadian yang diminati yaitu berupa informasi yang tersedia di pasar.

2. Membangun teori yang mampu memberikan alasan atau menjelaskan respon keuangan terhadap kejadian tersebut.

3. Mengidentifikasi tanggal kejadian (event dates).

4. Memilih event windows yang cocok sesuai dengan justifikasi jaraknya.

5. Menyesuaikan perusahaan-perusahaan yang mengalami kejadian tersebut.

6. Menghitung abnormal return selama event windows dan menguji tingkat signifikansinya.

\section{Abnormal return}

Studi peristiwa (event study) dilakukan untuk menganalisis abnormal return dari sekuritas yang mungkin terjadi di sekitar pengumuman suatu peristiwa. Abnormal return atau excess return merupakan kelebihan dari return yang sesungguhnya terjadi terhadap return normal. Dengan demikian abnormal return adalah selisih antara return sesungguhnya yang terjadi dengan return expektasinya. Brown dan Warner (1985) dalam Jogiyanto (2014) mengestimasi expected return dengan menggunakan tiga model yaitu mean-adjusted model, market model dan market-adjusted model.

Riset Akuntansi dan Keuangan Indonesia, 1(2), 2016

\section{Penelitian Terdahulu}

Dalam melakukan penelitian ini tidak lepas dari referensi penelitian yang sudah dilakukan sebelumnya. Sirait. dkk (2012) menyebutkan dalam hasil penelitiannya bahwa pada sektor perbankan terdapat perbedaan Average Abnormal Return (AAR) sebelum, saat dan sesuah peristiwa pengumuman pergantian menteri keuangan

Dari Lamasigi dan Treisye (2002) menyimpulkan hasil penelitiannya mengenai event study pergantian Presiden RI tanggal 23 Juli 2001 pada saham LQ 45 menyebutkan bahwa terdapat positif abnormal return sebelum dan sesudah event.

Hasil penelitian yang sama pula dilakukan oleh Nurhaeni dan Nunung (2009) dalam Sirait. dkk (2012) yang menyebutkan bahwa terdapat perbedaan AAR sebelum dan sesudah peristiwa pemilu legislatif pada tahun 2009. Sedangkan Nurita (2014) dalam hasil penelitiannya mengenai Event study: pengumuman quick count pemilu legislatif 2014, hasilnya menunjukkan abnormal return saham sebelum dan setelah pengumuman hasil quick count pemilu legislatif 2014, secara signifikan berbeda sehingga hal ini menunjukkan bahwa pasar bereaksi akan informasi pengumuman quick count.

Namun demikian dari beberapa hasil penelitian terdahulu yang sebagian besar memberikan hasil yang tidak jauh berbeda maka ada perbedaan hasil penelitian yang dilakukan oleh Pratama. dkk (2015), mengenai tema peneitian Event study: pemilihan Joko Widodo sebagai Presiden RI, memberikan hasil bahwa tidak ada reaksi yang signifikan terhadap peristiwa tersebut, artinya informasi tidak begitu sensitif bagi investor.

\section{Pengembangan Hipotesis}

Hasil penelitian event study yang dirujuk dari beberapa persistiwa yang terjadi di Indonesia memberikan beragam reaksi pasar terhadap informasi yang dipilih oleh peneliti, peristiwa-peristiwa yang terjadi di dalam negeri baik dari segi ekonomi maupun politik akan memberikan damak terhadap kinerja perusahaan terutama dalam menghasilkan profit/laba. Informasi yang positif tentunya akan memberikan dampak yang baik pula bagi perekonomian dalam negeri dan kesejahteraan para pemegang saham akan meningkat pula tetapi jika informasi tersebut membawa suhu negative maka value perusahaan juga akan ikut menurun. 
Berbagai penelitian mengenai event study sudah cukup banyak dilakukan, Sirait. dkk (2012), Lasmigi dan Treisye (2002) dan Nurita (2014) memberikan kesimpulan yang hampir sama bahwa pasar bereaksi positif artinya dari informasi tersebut terdapat adanya perbedaan Average Abnormal Return (AAR). Tetapi ada penelitian yang memberikan hasil berbeda yaitu penelitian dari Pratama. dkk (2015) dan Ananto (2014) yaitu tidak ada pengaruh yang signifikan secara statistik terhadap abnormal return, artinya tidak ada kandungan informasi yang cukup berarti terhadap investor.

Sehingga dari berbagai referensi pada penelitian terdahulu, maka terbentuklah hipotesis di bawah ini:

$\mathrm{H}_{1}$ : Terdapat perbedaan Average Abnormal Return $(A A R)$ sebelum dan saat peristiwa bom Plaza Sarinah

$\mathrm{H}_{2}$ : Terdapat perbedaan Average Abnormal Return $(A A R)$ saat dan sesudah peristiwa bom Plaza Sarinah

$\mathrm{H}_{3}$ : Terdapat perbedaan Average Abnormal Return $(A A R)$ sebelum dan sesudah peristiwa bom Plaza Sarinah.

\section{Metode Penelitian}

Populasi dalam penelitian ini adalah seluruh perusahaan yang terdaftar di Bursa Efek Indonesia periode tahun Desember 2015 - Januari 2016. Kriteria pemilihan sampel menggunakan metode purposive sampling, yaitu perusahaan-perusahaan yang terdaftar dalam index LQ 45, minimal satu bulan sebelum tanggal 14 Januari 2016.

\section{Jenis dan Sumber Data}

Data yang digunakan dalam penelitian ini merupakan jenis data sekunder yang sudah tersedia dan diperoleh dari website $w w w . i d x . g o . i d$, IDX fact book, www.financeyahoo.com. Data sekunder yang digunakan diantaranya adalah:

1. Tanggal terjadinya peristiwa (event date) bom Plaza Sarinah, yaitu tanggal 14 Januari 2016.

2. Daftar perusahaan yang tergabung dalam indeks LQ 45 pada bulan Desember 2015 Januari 2016.

3. Data penutupan harga saham (closing price)

4. Index Harga Saham Gabungan (IHSG)

Berikut definisi operasional variabel yang tercantum di bawah ini:

Riset Akuntansi dan Keuangan Indonesia, 1(2), 2016
1. Return saham

Return saham yang diperoleh dengan menggunkan logaritma natural (ln) yaitu membagi harga penutupan akhir bulan dengan harga penutupan akhir bulan sebelumnya.

$$
\text { Rit }=\ln (\text { Pit/Pit-1) }
$$

(Hartono, 2014)

2. Return pasar

Return pasar yang digunakan adalah IHSG. Untuk perhitungannya menggunakan logaritma natural (ln) yaitu dengan menghitung IHSG bulan $\mathrm{t}$ dibagi dengan IHSG pada bulan $\mathrm{t}-1$ (bulan sebelumnya).

$$
R m t=\ln (\text { IHSGt/IHSGt-1) }
$$

(Hartono, 2014)

3. Abnormal return (AR)

Abnormal return (AR) saham dihitung menggunkan metode market adjusted model dengan mencari selisih return bulanan masingmasing sampel dengan return indeks pasar yang diwakili oleh return IHSG bulanan.

$$
\text { ARit }=\text { Rit }- \text { Rmt }
$$

(Hartono, 2014)

4. Average Abnormal return (AAR)

Average Abnormal return dihitung dengan menjumlahkan abnormal return saham ke-i pada waktu ke-t dibagi dengan jumlah sampel penelitian.

$$
\text { AARit }=\sum A R / n
$$

(Hartono, 2014)

\section{Teknik Analisis Data}

Teknik analisis data dalam peneilitian ini dengan menggunakan event windows seperti pada Gambar 6.1 di bawah ini:

\section{Gambar 4.1 Event Windows}

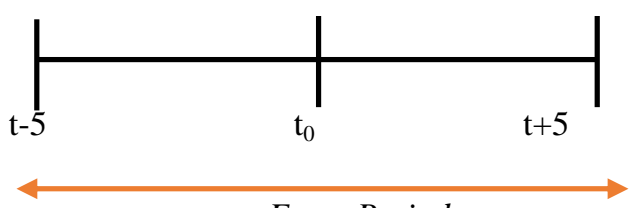

\section{Event Periode}

Dari event windows tersebut maka langkah-langkah yang harus dilakukan adalah:

1. Menentukan sampel perusahaan Index LQ 45 sesuai dengan kriteria.

2. Menentukan waktu penelitian (event date), t-5 yaitu 5 hari sebelum peristiwa bom Plaza Sarinah. $\mathrm{t}_{0}$ yaitu saat peristiwa bom Plaza Sarinah dan $t+5$ yaitu peristiwa setelah 
terjadinya peristiwa bom Plaza Sarinah di Jakarta.

3. Mencatat harga penutupan saham harian sesuai sampel perusahaan yang sudah ditentukan pada event periode.

4. Mencatat IHSG pada event periode.

5. Melakukan perhitungan return saham harian $\left(R_{i t}\right)$ yang diambil dari harga saham penutupan (closing price), dengan menggunakan rumus berikut ini:

$$
\boldsymbol{R}_{i t}=\ln \left(\boldsymbol{P}_{i t} / \boldsymbol{P}_{i t-1}\right)
$$

Dimana:

$$
\begin{array}{ll}
R_{i t} & \text { : Return saham ke i untuk } \\
& \text { bulan ke-t } \\
\text { ln } & \text { : Logaritma natural } \\
P_{i t} & \text { : Harga penutupan untuk } \\
& \text { saham i pada bulan ke-t. } \\
P_{i t-1} & \text { : Harga penutupan untuk } \\
& \text { saham i pada bulan } \\
& \text { sebelumnya. }
\end{array}
$$

6. Melakukan perhitungan Return pasar bulanan $\left(R_{m t}\right)$. Dengan menggunakan rumus di bawah ini:

$$
R_{m t}=\ln \left(\text { IHSG }_{t} / I H S G_{t-1}\right) \ldots \ldots
$$

Dimana:

$$
\begin{array}{lc}
R_{m t} & \text { : Return market pada } \\
& \text { bulan ke-t } \\
\text { ln } & \text { : Logaritma natural. } \\
I H S G_{t}: \text { Index Harga Saham } \\
\\
\\
\text { Gabungan (IHSG) } \\
\text { pada bulan ke-t. } \\
I H S G_{t-1} \quad \text { : Index Harga Saham } \\
\text { Gabungan (IHSG) pada bulan } \\
\text { sebelumnya. }
\end{array}
$$

7. Menghitung Abnormal return $\left(A R_{i t}\right)$ dengan menggunakan metode market adjusted model, dengan rumus sebagai berikut:

$$
A \boldsymbol{R}_{i t}=\boldsymbol{R}_{i t}-\boldsymbol{R}_{m t} \ldots \ldots \ldots \ldots \ldots \ldots
$$

Dimana:

$A R_{\text {it }}$ : Abnormal return saham i pada bulan ke-t

$R_{i t} \quad$ : Return saham i pada bulan ke-t.

$R_{m t} \quad$ : Return market (return pasar) pada bulan ke-t.

8. Menghitung Average Abnormal return (AAR), dengan rumus sebagai berikut:

$$
\boldsymbol{A A R} \boldsymbol{R}_{i t}=\sum_{t=1} n \boldsymbol{A} \boldsymbol{R}_{i t}
$$

Dimana:

$$
\begin{array}{ll}
A A R_{i t}: & \text { Rata-rata Abnormal } \\
& \text { return saham pada periode } \\
& \text { ke-t. } \\
A R_{i t} & : \text { Abnormal return saham i } \\
& \text { pada periode ke-t. } \\
n & \text { : Jumlah observasi atau } \\
& \text { jumlah periode. }
\end{array}
$$

9. Data dianalisis dengan menggunakan uji beda Paired Sample t-test dengan bantuan program Excel 2013 dan Softwere SPSS 21.

10. Menarik kesimpulan.

\section{Pengujian Hipotesis}

Untuk mengetahui tingkat signifikansi dari hipotesis yang dibentuk dalam penelitian ini yaitu dengan menggunakan uji beda Paired Sample t-test, atau uji beda rata-rata dua sampel yang berpasangan, dengan taraf signifikansi yang digunakan adalah 5\% $(0.05)$

Prasyarat yang harus dipenuhi dalam uji beda Paired Sample t-test adalah jika nilai signifikansi hasil penelitian > 0,05 maka Ho diterima dan jika nilai signifikansi hasil penelitian $<0.05$ maka Ho ditolak. Jika akan membendingkan antara $\mathrm{t}$ hitung dengan $\mathrm{t}$ tabel, kriterianya adalah jika $\mathrm{t}$ hitung $>\mathrm{t}$ tabel maka Ho ditolak dan sebaliknya jika $\mathrm{t}$ hitung $<\mathrm{t}$ tabel maka Ho diterima.

Hipotesis yang dibentuk dalam penelitian event study: bom Plaza Sarinah, seperti tercantum dibawah ini:

$\mathbf{H}_{1}$ : Menguji perbedaan rata-rata (average) abnormal return pada waktu sebelum dan saat peristiwa bom Plaza Sarinah.

$\mathbf{H}_{2}$ : Menguji perbedaan rata-rata (average) abnormal return pada saat dan sesudah peristiwa bom Plaza Sarinah

$\mathbf{H}_{3}$ : Menguji perbedaan rata-rata (average) abnormal return pada waktu sebelum dan sesudah peristiwa bom Plaza Sarinah.

\section{Hasil dan Pembahasan}

Ada tiga hipotesis yang akan diuji dalam penelitian ini yaitu H1: Menguji perbedaan rata-rata (average) abnormal return pada waktu sebelum dan saat peristiwa bom Plaza Sarinah, H2: Menguji perbedaan rata-rata (average) abnormal return pada saat dan sesudah peristiwa bom Plaza Sarinah dan H3: Menguji perbedaan rata-rata (average) abnormal 
return pada waktu sebelum dan sesudah peristiwa bom Plaza Sarinah.

Pengujian H1: Menguji perbedaan rata-rata (average) abnormal return pada waktu sebelum dan saat peristiwa bom Plaza Sarinah.

Tahap pengujian $\mathrm{H} 1$ adalah dengan menggunakan paired sample t-test, dimana data yang digunakan adalah rata-rata abnormal return (AAR) yang akan dibandingkan antara AAR sebelum kejadian bom Sarinah Jakarta dengan AAR saat kejadian bom Sarinah Jakarta. Hasil analisis tersebut akan disajikan dalam Tabel 4.1.

Jika dilihat dari $\mathrm{t}$ hitungnya semua bernilai positif dengan nilai t tabel 1.303 (taraf 10\%), 1.684 (taraf 5\%) dan 2.423 (taraf 1\%) maka nilai t hitung semuanya kurang dari t tabel. Bila dilihat dari taraf signifikansinya terlihat sangat jelas semua nilai signifikansi hasil analisis lebih besar dari taraf signifikansi yang sudah ditentukan.

Dapat disimpulkan bahwa jika t hitung $<\mathrm{t}$ tabel maka Ho diterima, dan bila nilai signifikansi hasil penelitian > taraf signifikansi hasilnya Ho diterima, yaitu Tidak ada perbedaan rata-rata (average) abnormal return (AAR) pada waktu sebelum dan saat peristiwa bom Plaza Sarinah.

Pengujian H2: Menguji perbedaan rata-rata (average) abnormal return pada saat dan sesudah peristiwa bom Plaza Sarinah

Pada pengujian $\mathrm{H} 2$, tidak jauh berbeda dengan analisis di hipotesis pertama, yang membedakan adalah data AAR yang akan diuji yaitu AAR pada saat peristiwa dan AAR sesudah peristiwa bom Sarinah Jakarta. Hasil analisis tersebut akan disajikan dalam Tabel 4.2.

Dapat disimpulkan bahwa pada $\mathrm{H}+1, \mathrm{H}+2, \mathrm{H}+4$ dan $\mathrm{H}+5$ tidak ada pengaruh yang cukup signifikan

\begin{tabular}{|c|c|c|c|c|}
\hline \multicolumn{5}{|c|}{ ah peristiwa Bom Sarinah } \\
\hline Kriteria & $\begin{array}{c}\text { AAR } \\
\text { Sesudah } \text { event }\end{array}$ & $\begin{array}{c}\text { AAR } \\
\text { Saat event }(\mathrm{H} 0)\end{array}$ & t-hitung & sig \\
\hline Ho dan $\mathrm{H}+1$ & -9.177 & -6.082 & 0.385 & 0.702 \\
\hline H0 dan $\mathrm{H}+2$ & -3.995 & -6.082 & -0.235 & 0.816 \\
\hline HO dan $\mathrm{H}+3$ & 1.235 & -6.082 & -1.831 & $0.074^{*}$ \\
\hline Ho dan $\mathrm{H}+4$ & -1.477 & -6.082 & 0.943 & 0.351 \\
\hline Ho dan $\mathrm{H}+5$ & -4.234 & -6.082 & -0.169 & 0.867 \\
\hline $\begin{array}{l}\text { *tingkat signi } \\
* * \text { tingkat sign } \\
\text { ***tingkat si }\end{array}$ & $\begin{array}{l}10 \% \\
\text { si } 5 \% \\
\text { nsi } 1 \% \\
\end{array}$ & & & \\
\hline
\end{tabular}

dan tidak ada perbedaan AAR, hanya pada $\mathrm{H}+3$ saja yang menunjukkan adanya pengaruh peristiwa tersebut terhadap pergerakan saham, terutama untuk saham LQ 45 dan memberikan signal informasi yang cukup kuat kepada para investor dari dampak peristiwa tersebut.

Pengujian H3: Menguji perbedaan rata-rata (average) abnormal return pada waktu sebelum dan sesudah peristiwa bom Plaza Sarinah.

Pengujian H3 masih sama menggunakan metode paired sample t-tes, untuk melihat adanya atau tidaknya perbedaan AAR pada sebelum dan sesudah peristiwa bom Sarinah. Untuk hasil analisis yang lebih lengkapnya akan disajikan dalam Tabel 4.3. Tabel 4.3 yang memberikan gambaran mengenai hasil analisis H3 hasilnya tidak jauh berbeda dengan analisis $\mathrm{H} 2$, karena hanya pada $\mathrm{H}+3$ yang menunjukkan adanya perbedaan AAR dan taraf signifikansi ada di waktu $\mathrm{H}+3$ dan $\mathrm{H}+4$ yang artinya $\mathrm{H} 0$ ditolak.

Reaksi yang terjadi akibat adanya peristiwa bom Sarinah ini membuktikan bahwa adanya kandungan informasi yang cukup berpengaruh terhadap para pelaku pasar khususnya investor. Secara umum sebenarnya peristiwa ini berdampak sistemik

Tabel 4.3
\begin{tabular}{|c|c|c|c|c|}
\hline Pengujian AAR sebelum dan AAR sesudah peristiwa Bom Sarinah \\
\hline Kriteria & $\begin{array}{c}\text { AAR } \\
\text { Sebelum } \text { event }\end{array}$ & $\begin{array}{c}\text { AAR } \\
\text { Sesudah } \text { event }\end{array}$ & t-hitung & sig \\
\hline $\mathrm{H}-5$ dan $\mathrm{H}+1$ & -2.994 & -9.177 & 0.667 & 0.508 \\
\hline $\mathrm{H}-4$ dan $\mathrm{H}+2$ & 3.563 & -3.995 & 0.817 & 0.418 \\
\hline $\mathrm{H}-3$ dan $\mathrm{H}+3$ & -1.599 & 1.235 & -1.735 & $0.090^{*}$ \\
\hline $\mathrm{H}-2$ dan $\mathrm{H}+4$ & 1.580 & -1.477 & 2.021 & $0.049^{* *}$ \\
\hline $\mathrm{H}-1$ dan $\mathrm{H}+5$ & 2.412 & -4.234 & 0.697 & 0.489 \\
\hline *tingkat signifikansi $10 \%$ & & & \\
\hline **tingkat signifikansi 5\% \\
***tingkat signifikansi $1 \%$
\end{tabular}
Sumber: data diolah, 2016

terhadap berbagai sektor di Negara Indonesia tetapi lebih spesifiknya dampak dalam kajian ekonomi akan lebih memiliki pengaruh yang cukup signifikan walaupun reaksinya tidak secara langsung.

Penjelasan dari semua hipotesis diatas akan disajikan pula dalam bentuk grafik secara khusus nilai AAR pada sebelum, saat dan sesudah peristiwa bom Sarinah Jakarta, dalam grafik 4.1. 


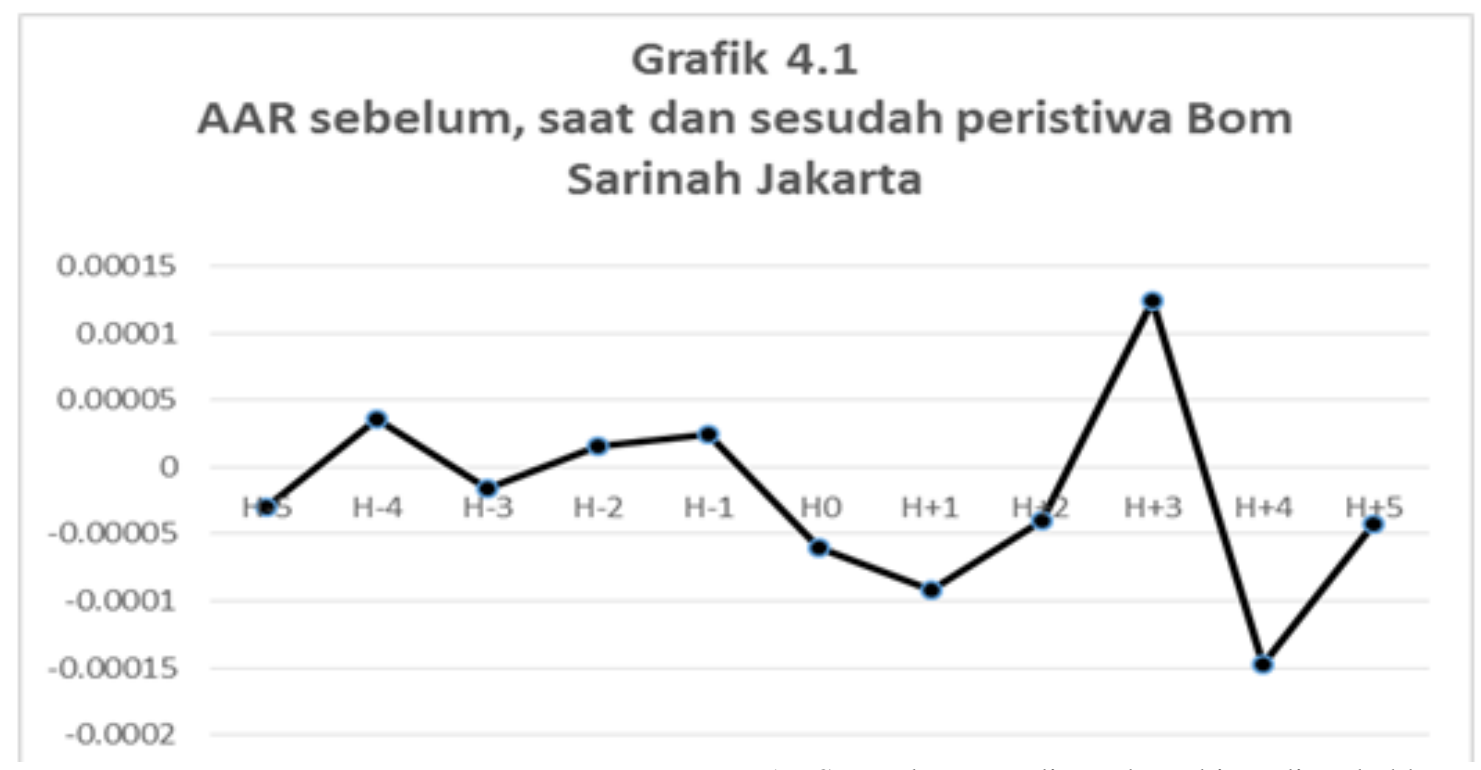

\section{Simpulan \\ Simpulan}

Berdasarkan hasil analisis dari uji hipotesis diatas maka peneliti dapat memberikan beberapa kesimpulan seperti dibawah ini:

1. Hipotesis pertama, memberikan gambaran bahwa tidak ada perbedaan rata-rata abnormal return pada saham-saham LQ 45. Diperkirakan karena perbandingannya sebelum kejadian secara umum pengaruh informasi ada tetapi penyebab pengaruh tersebut bukan karena adanya peristiwa bom Sarinah di Jakarta.

2. Hipotesis kedua dan hipotesis ketiga hampir sama karena data AAR yang digunakan dalam pengujian hipotesis ini setelah peristiwa pengeboman maka pada $\mathrm{H}+3$ dan $\mathrm{H}+4$ terjadi reaksi atas persitiwa tersebut pada pergerakan harga saham dan tentunya hal ini memberikan pengaruh yang cukup kuat bagi para pelaku pasar terutama para investor, walaupun reaksi yang terjadi tidak secara langsung pada hari sesudahnya.

3. Penelitian ini sangat sensitif terhadap data dan sampel yang digunakan, karena data yang digunakan bersifat harian dalam jangka waktu yang sangat singkat.

\section{Saran}

Dalam setiap penelitian pasti ada kekurangan begitupun kelebihannya, berikut beberapa saran yang peneliti sampaikan untuk melengkapi kekurangan pada penelitian ini:

Riset Akuntansi dan Keuangan Indonesia, 1(2), 2016
1. Sampel yang digunakan bisa ditambahkan dari bidang industri yang berbeda.

2. Jumlah sampel untuk penelitian semakin banyak semakin robust.

3. Bisa menggabungkan beberapa event dalam satu penelitian yang memiliki hubungan dan konteks yang berdekatan. Misalnya: dalam bidang politik (pemilihan umum / resufle mentri dan sebagainya).

4. Data dalam penelitian ini menggunakan adjusted closing price, untuk penelitian lanjutan bisa membandingkan dengan data closing price (yang belum disesuaikan) sehingga bisa melihat perbandingan kedua data tersebut setelah dilakukan analisis.

5. Waktu event sebelum dan sesudahnya bisa ditambahkan lebih lama dengan tujuan adanya kemungkinan dampak informasi lain yang berpengaruh terhadap event study tersebut.

\section{Daftar Pustaka}

[1] Ananto, Dedy (2014). Pengaruh Pemilu Legislatif Terhadap Abnormal Return Dan Trading Volume Activity Saham Di Jakarta Islamic Index (Studi Kasus Pada Peristiwa Pemilu Legislatif 09 April 2014). Tesis. Fakultas Syari'ah dan Hukum. UIN Sunan Kalijaga

[2] Bodie, et al. 2011. Investment and Portofolio Management. McGraw-Hill

[3] Dosinta, Nina F. 2004. Weak Form of Market Efficient Hypothesis: To See the Increase of Efficiency on Two Different Periods. Tesis Magister Akuntansi. FEB UGM: tidak dipublikasikan 
[4] Fama, E, F., et al. 1969. The Adjustment Of Stock Prices To New Information. International Economic Review. Vol. 10, No. 1. Februari

[5] Hartono. J. 2014. Teori Portofolio dan Analisi Investasi. Edisi kesembilan. BPFE. Yogyakarta.

[6] Husnan, Suad. 2009. Teori Portofolio dan Analisis Sekuritas. UPP STIM YKPN. Yogyakarta

[7] Pratama, dkk. 2015. Reaksi Pasar Modal Indonesia Terhadap Peristiwa Politik (Event study Pada Peristiwa Pelantikan Jokowi Sebagai Presiden Republik Indonesia Ke-7). EJurnal Universitas Pendidikan Ganesha Vol. 3, No.1

[8] Lamasigi, dkk. 2002. Reaksi Pasar Modal terhadap Peristiwa Pergantian Presiden Republik Indonesia 23 Juli 2001 : Kajian Terhadap Return Saham LQ-45 Di PT. Bursa Efek Jakarta. Simposium Nasional Akuntansi V Semarang

[9] Nurita, Dea. 2014. Event study: Pengumuman Quick Count Pemilu Legislatif 2014. Artikel tidak dipublikasikan.

[10] Setyawasih, Rianti. 2007. Studi Tentang Peristiwa (Event study) Suatu Panduan Riset Manajemen Keuangan Di Pasar Modal. Jurnal Optimal. Vol. 1, No. 1. Maret

[11] Sartono. Agus. 1999. Manajemen Keuangan Teori dan Aplikasi. Edisi ketiga. BPFE. Yogyakarta

[12] Sirait, dkk. 2012. Dampak Pergantian Mentri Keuangan RI Tahun 2010 Terhadap Abnormal Return Perusahaan perbankan yang terdaftar di BEI. E-Jurnal Binar Akuntasi. Vol.1 No.1, September.

[13] Trihendradi, C. 2013. Step By Step IBM SPSS 21: Analisis Data Statistik. Andi. Yogyakarta.

[14] Wicaksono, Bambang W. 2005. Pengujian Price Reversal Terhadap Saham-Saham di Bursa Efek Jakarta. Tesis Magister Sains Management. FEB UGM: tidak dipublikasikan.

[15] https://id.wikipedia.org/wiki/Serangan_Jakarta $\underline{2016}$

[16] Zaqi, Mochamad. 2006. Reaksi Pasar Modal Terhadap Peristiwa-Peristiwa Ekonomi Dan Peristiwa-Peristiwa Social Politik Dalam Negeri (Studi Pada Saham LQ 45 di BEJ Periode Tahun 1999-2003). Tesis Magister Manajemen FEB UNDIP. 